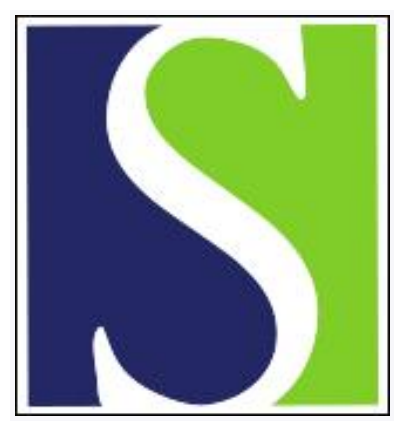

Scand J Work Environ Health 1992;18(1):44-51

https://doi.org/10.5271/sjweh.1609

Issue date: 28 Feb 1992

Occupational airborne exposure of the general population of a Norwegian county.

by Bakke P, Baste V, Hanoa R, Gulsvik A

Affiliation: Department of Thoracic Medicine, University of Bergen, Norway.

This article in PubMed: www.ncbi.nlm.nih.gov/pubmed/1553512

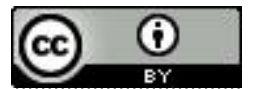




\title{
Occupational airborne exposure of the general population of a Norwegian county
}

\author{
by Per Bakke, MD, Valborg Baste, Rolf Hanoa, MD, Amund Gulsvik, MD'1
}

\begin{abstract}
BAKKE P, BASTE V, HANOA R, GULSVIK A. Occupational airborne exposure of the general population of a Norwegian county. Scand J Work Environ Health 1992;18:44-51. Occupational airborne exposure was examined for a stratified sample $(\mathrm{N}=1275)$ of the general population aged $18-73$ years in Hordaland County, Norway. The subjects identified all jobs of more than six months since leaving school and stated whether they had been occupationally exposed to specific agents and work processes potentially harmful to the lungs. The prevalence in the population ever having been exposed was $18 \%$ for asbestos, $9 \%$ for quartz, $5 \%$ for aluminum dust, $6 \%$ for wood dust, $12 \%$ for metal gases, $12 \%$ for welding, $9 \%$ for soldering, and $1 \%$ for hairdressing. According to occupational title (last job), $3 \%$ of the population had held a job with a high degree of airborne exposure, $26 \%$ a job with moderate exposure, and $70 \%$ a job with no airborne exposure. During their worklife both the men and the women tended to leave polluted jobs more often than unpolluted jobs. Occupational exposure to airborne pollutants potentially harmful to the lungs is widespread in this Norwegian general population.
\end{abstract}

Key terms: epidemiology, occupational airborne agents, occupational titles, population survey, work processes.

One objective of occupational epidemiology is to identify subjects exposed to agents or work processes that are hazardous to human health. The outcome variables in this research have usually been well defined entities. The exposure characterization, however, is often less precise because of its complexity and variability. In community surveys occupational exposure characterization has mainly been based on title of present job or the job held the longest (1). However, these entities may be poor indicators of lifetime exposure. Nevertheless, occupational title has shown to be a marker for both lung cancer $(2,3)$ and obstructive lung disease (4). Few community surveys have focused on complete work histories of subjects in general population samples (5).

Studies of working populations have identified numerous agents as being potentially harmful to the airways (6). However, little is known of the exposure prevalence of specific airborne agents or their combinations in the community $(7,8)$.

The objectives of the present study were to characterize airborne exposure at work in the general population by means of occupational titles. Furthermore we wanted to obtain community-based prevalence estimates of past or present occupational exposure to some specific agents and work processes harmful to the lungs.

\footnotetext{
1 Department of Thoracic Medicine, University of Bergen, Bergen, Norway.
}

Reprint requests to: Dr P Bakke, Department of Thoracic Medicine, N-5021 Haukeland Hospital, Norway.

\section{Subjects and methods}

\section{Study area and study population}

The Hordaland survey is a two-phased cross-sectional study of the general population of Hordaland county, on the southwest coast of Norway. The county comprises $10 \%$ of the Norwegian population. The 1980 census (9) showed that the working population of the county was occupied in private and public services $(64 \%)$, industry $(21 \%)$, constrüction $(9 \%)$, and agriculture and fishing $(5 \%)$. The corresponding figures for Norway were $62,19,11$, and $8 \%$, respectively (9). of those working in industry in Hordaland, $43 \%$ were occupied in engineering, $17 \%$ in shipbuilding, $15 \%$ in the food industry, $11 \%$ in the graphics and publishing industry, $8 \%$ in the textile industry, and $7 \%$ in the iron and metal industry (9).

In the first phase of the study, conducted in 1985, a questionnaire was mailed to a random sample of 4992 persons of the general population aged $15-70$ years (10). The questionnaire contained questions on smoking habits, past or present occupational dust or gas exposure, including asbestos and quartz (11), and respiratory symptoms and physician's diagnosis of asthma (12). The response rate was $90 \%$ of the sample. The respondents $(\mathrm{N}=3370)$ living in Bergen or one of 11 surrounding municipalities were divided into two strata on the basis of the information obtained from the postal survey. The first stratum contained subjects who had received a physician's diagnosis of asthma and emphysema or who had been occupationally exposed to asbestos or quartz or nonsmokers without respiratory symptoms. The second stratum contained those not included in the first. In the second phase, conducted from 1987 to 1988 , a $91 \%$ random sample of the sub- 
jects in stratum 1 and a $22 \%$ random sample of the subjects in stratum 2, altogether 1512 subjects, were invited to attend a standardized clinical examination. The overall attendance rate was $84 \%$ of those invited. The attendants and nonattendants in the second phase of the study were comparable as to gender, while the attendants were significantly older than the nonattendants (table 1). According to information from the questionnaire phase of the survey no significant difference existed between the attendants and nonattendants regarding smoking habits and occupational exposure to dusts or gases and quartz. A history of occupational asbestos exposure was significantly more frequent among the attendants than among the nonattendants (table 1).

\section{Exposure characterization}

At the clinical examination all of the subjects completed an occupational history questionnaire. They were instructed to state all jobs held for at least six months since leaving school, beginning with the present job and listing backwards, and to provide starting and finishing year of each job. In the second part of the questionnaire they were asked whether they had been occupationally exposed to 11 agents and work processes potentially harmful to the airways. The agents and work processes were asbestos, quartz, aluminum production and processing, wood dust, metal gases (chromium, nickel, platinum), isocyanates, aldehydes, anhydrides, welding, soldering, and hairdressing. The alternatives for answering were "yes" and "no." Regarding asbestos, quartz, aluminum, and wood dust, the subjects were asked to pick out the branch of industry or work process in which they had been mostly exposed to the agents from a list of printed alternatives. For asbestos and quartz the subjects were also asked to state the degree of exposure, and for asbestos whether they had been exposed daily, weekly, monthly, or more seldom.

The questionnaire was checked for completeness by a nurse and a physician. This control showed that a majority of the subjects were not familiar with the terms isocyanates, aldehydes, and anhydrides, and they did not answer the questions concerning the compounds. In the following analyses the data on these agents were therefore excluded.

For each job the subjects recorded the occupational title. For the present report job was defined as an engagement, while occupational title was defined as a profession. Hence a subject may have had one occupational title and several jobs, but not vice versa.

The occupational title of each job was coded according to the three-digit numbers of the Nordic Classification of Occupations (13), which follows the recommendations of the International Standard Classification of Occupations (14). The occupational titles were allocated into the following three exposure categories: high degree of exposure $(\mathrm{AE}++)$ : occupations in which most workers regularly experience a high degree of airborne exposure; moderate degree of exposure $(\mathrm{AE}+)$ : occupations in which most workers regularly experience a moderate degree of airborne exposure; no exposure $(\mathrm{AE}-)$ : occupations in which most workers regularly experience trivial or no airborne exposure. The term "airborne exposure" included dusts, fumes, mists, and gases $(6,15)$. The definition of "high" and "moderate" airborne exposure was based on the judgement of those performing the allocation. It was performed by two experienced occupational physicians and one industrial hygienist who did not participate in the field work otherwise. They agreed on the classification for 196 of the 213 occupational titles (overall agreement $92 \%$ ). In cases of disagreement occupation was classified according to the majority of the evaluators.

Examples of $\mathrm{AE}++$ occupations (18 titles) were concrete and construction workers, welders and painters. AE + occupations (71 titles) comprised such titles as cleaners, joiners, and engineering workers. AE - occupations (124 titles) were, for instance, clerks, shop assistants, and teachers. Housewife was not included in the Nordic Classification of Occupations. In the present study housewife was regarded as an occupation in the $\mathrm{AE}$ - group. The complete list of occupations allocated into the three exposure groups can be obtained from the senior author.

Table 1. Characteristics of the attendants and nonattendants in the second phase of the general population survey of Bergen and 11 surrounding municipalities.

\begin{tabular}{|c|c|c|c|c|c|c|c|c|c|c|c|c|}
\hline & \multirow{4}{*}{$\begin{array}{c}\text { Women } \\
(\%)\end{array}$} & \multicolumn{2}{|c|}{ Age $^{a}$ (years) } & \multicolumn{5}{|c|}{ Smoking habits ${ }^{b}$} & \multirow{4}{*}{$\begin{array}{c}\text { Urban } \\
\text { area of } \\
\text { residencec } \\
(\%)\end{array}$} & \multicolumn{3}{|c|}{$\begin{array}{c}\text { Past or present } \\
\text { occupational exposure }\end{array}$} \\
\hline & & \multirow{3}{*}{ Mean } & \multirow{3}{*}{ SD } & \multicolumn{3}{|c|}{ Smokers } & \multirow{3}{*}{$\begin{array}{c}\text { Ex- } \\
\text { smokers } \\
(\%)\end{array}$} & \multirow{3}{*}{$\begin{array}{c}\text { Non- } \\
\text { smokers } \\
(\%)\end{array}$} & & \multirow{3}{*}{$\begin{array}{c}\text { Dust or } \\
\text { gas } \\
(\%)\end{array}$} & \multirow{3}{*}{$\begin{array}{c}\text { Asbes- } \\
\text { tos } \\
(\%)\end{array}$} & \multirow{3}{*}{$\begin{array}{l}\text { Quartz } \\
(\%)\end{array}$} \\
\hline & & & & \multirow{2}{*}{$\%$} & \multicolumn{2}{|c|}{ Cigarettes/d } & & & & & & \\
\hline & & & & & Mean & SD & & & & & & \\
\hline $\begin{array}{l}\text { Attendants } \\
(\mathrm{N}=1275)\end{array}$ & 49 & 42 & 16.1 & 29 & 15 & 5.5 & 14 & 57 & 68 & 32 & 10 & 8 \\
\hline $\begin{array}{l}\text { Nonattendants } \\
(\mathrm{N}=237)\end{array}$ & 47 & 37 & 16.9 & 27 & 14 & 6.8 & 15 & 59 & 68 & 30 & 6 & 8 \\
\hline
\end{tabular}

a Age on 31 December 1987.

- Information from the postal questionnaire.

c Living in the municipality of Bergen. 
The subjects were classified as smokers if they were smoking daily at the time of the study (11). Nonsmokers were defined as subjects who had never smoked daily. Ex-smokers were subjects who used to smoke daily but had given it up.

\section{Analysis}

The differences between the attendants and nonattendants were examined with chi-square tests of the

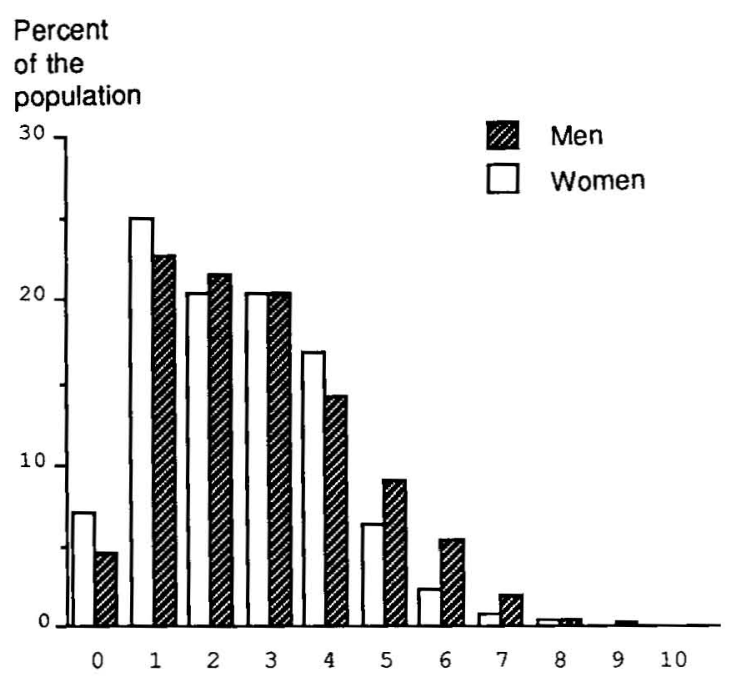

Number of occupational titles throughout professional career

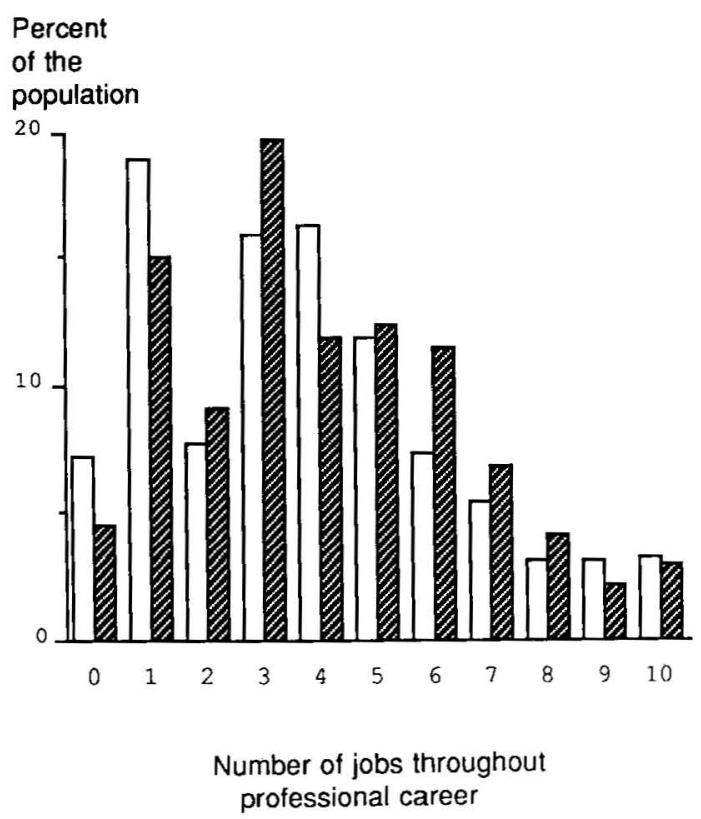

Figure 1. Number of occupational titles and jobs held during the professional career of 1275 men and women aged 18-73 years in Bergen and 11 surrounding municipalities.
BMDP (biomedical data package) program (16). All of the prevalence estimates given in tables $2-5$ and in figure 1 were corrected for the different sampling fractions of the two strata (17) and are hence community representative estimates. Differences in frequencies and tests for trends were performed with a weighed regression analysis. For all the analyses a significance level of $\mathrm{P}=0.05$ was used.

\section{Results}

One, two, and three occupational titles held since leaving school were each stated by approximately $20 \%$ of the men and women (figure 1, upper half). Five or more occupational titles were stated by $19 \%$ of the men and by $10 \%$ of the women. The mode number of jobs held since leaving school and lasting for at least six months were three for the men and one for the women (figure 1, lower half). Altogether $27 \%$ of the men and $22 \%$ of the women had been employed in more than five jobs. More than five jobs was significantly more frequently seen for those $35-54$ years of age $(39 \%)$ than for those $18-34$ years of age $(14 \%)$ or those $55-73$ years of age $(22 \%)$. The number of jobs did not vary with smoking habits. According to the longest job held, the five most common occupations (percentage of the population) were housewives $(9.9 \%)$, clerks $(7.6 \%)$, shop assistants $(5.2 \%)$, general managers $(5.1 \%)$, and cleaners $(3.2 \%)$. Of the 10 most commonly held occupations six were $\mathrm{AE}$ - occupations and four were $\mathrm{AE}+$ occupations.

On the basis of the occupational title of the longest job held, $40 \%$ of the population aged $18-73$ years had been employed in a job with a high or moderate degree of airborne exposure (table 2). The corresponding figure for the last job held was $29 \%$. The highly exposed occupations were five to six times more prevalent among the men than among the women. According to both the last and longest job held, the prevalence of subjects with $\mathrm{AE}$ - jobs tended to decrease as age increased. Higher percentages of ever-smokers had held $\mathrm{AE}++$ and $\mathrm{AE}+$ jobs than nonsmokers (table 2). AE - jobs were more prevalent in urban than in rural areas.

To examine how the subjects moved between the exposed and unexposed occupations during their career, we followed the 1921-1936 cohort from 1957 to 1987 (table 3). For both genders workers holding an AEoccupation in 1957 stayed in the same exposure group longer than workers having an $\mathrm{AE}+$ or $\mathrm{AE}++$ occupation in 1957. The transition from $\mathrm{AE}+$ or $\mathrm{AE}++$ to $\mathrm{AE}$ - occupations was greater than in the other direction. Men with airborne occupational exposure tended to leave the work force more often than men without such exposure.

The estimated lifetime prevalences of occupational exposure to the specific agents and work processes, except for hairdressing, were much higher for the men 
than the women (table 4). Due to the low exposure rates of the women, the estimates for occupational exposure to the agents and work processes are only given for the men by age and smoking habits (table 4). The lifetime prevalence of exposure to asbestos increased with age. No age trend in occurrence was observed for any of the other agents or work processes. The male ever-smokers had been exposed to the agents or work processes almost twice as often as the male nonsmokers.

Occupational exposure to at least one of the eight agents or work processes was stated by $57 \%$ of the men and $3 \%$ of the women. Among the men exposure to one, two, three, four, five, and six of the agents or work processes was reported by $19,12,11,8,4$, and $2 \%$, respectively. The most commonly reported com- binations of two agents or work processes were welding and metal gases and asbestos and welding. Both combinations were reported by $23 \%$ of the male population. The most commonly reported combination of three agents or work processes was asbestos, metal gases, and welding, which was reported by $11 \%$ of the male population. Of the asbestos exposed, $9 \%$ had been exposed daily, $18 \%$ weekly, $24 \%$ monthly, and $49 \%$ more seldom than monthly. Sixteen percent regarded their exposure as of high degree, $70 \%$ as low, and $14 \%$ did not know. Of those with quartz exposure, $27 \%$ reported high-degree exposure, $63 \%$ stated that they had had low-degree exposure, and $10 \%$ did not know. Asbestos, quartz, aluminum, or wood dust were reported as the main exposure for several branches of industry and work processes (table 5).

Table 2. Prevalence estimates, and their standard errors (SE), of airborne occupational exposure according to the occupational title of the last job held and the job held longest by gender, age, smoking habits, and area of residence of a stratified sample of the general population aged 18-73 years from Bergen and 11 surrounding municipalities, $1987-1988 .^{a}$ (AE - = jobs with no airborne exposure, $\mathrm{AE}+=$ jobs with a moderate degree of airborne exposure, $\mathrm{AE}++=$ jobs with a high degree of airborne exposure)

\begin{tabular}{|c|c|c|c|c|c|c|c|c|c|c|c|c|c|}
\hline \multirow{4}{*}{ Category } & \multirow{4}{*}{ N } & \multicolumn{12}{|c|}{ Exposure status } \\
\hline & & \multicolumn{6}{|c|}{ Last job held } & \multicolumn{6}{|c|}{ Job held longest } \\
\hline & & \multicolumn{2}{|c|}{$\mathrm{AE}-$} & \multicolumn{2}{|c|}{$A E+$} & \multicolumn{2}{|c|}{$\mathrm{AE}++$} & \multicolumn{2}{|c|}{$A E-$} & \multicolumn{2}{|c|}{$\mathrm{AE}+$} & \multicolumn{2}{|c|}{$\mathrm{AE}++$} \\
\hline & & $\begin{array}{c}\text { Preva- } \\
\text { lence } \\
(\%)\end{array}$ & $\begin{array}{l}\mathrm{SE} \\
\langle \%\rangle\end{array}$ & $\begin{array}{l}\text { Preva- } \\
\text { lence } \\
(\%)\end{array}$ & $\begin{array}{l}\mathrm{SE} \\
(\%)\end{array}$ & $\begin{array}{l}\text { Preva- } \\
\text { lence } \\
(\%)\end{array}$ & $\begin{array}{l}\mathrm{SE} \\
(\%)\end{array}$ & $\begin{array}{l}\text { Preva- } \\
\text { lence } \\
(\%)\end{array}$ & $\begin{array}{c}\mathrm{SE} \\
(\%)\end{array}$ & $\begin{array}{l}\text { Preva- } \\
\text { lence } \\
(\%)\end{array}$ & $\begin{array}{l}\text { SE } \\
(\%)\end{array}$ & $\begin{array}{l}\text { Preva- } \\
\text { lence } \\
(\%)\end{array}$ & $\underset{(\%)}{\mathrm{SE}}$ \\
\hline \multicolumn{14}{|l|}{ Gender } \\
\hline $\begin{array}{l}\text { Male } \\
\text { Female }\end{array}$ & $\begin{array}{l}653 \\
622\end{array}$ & $\begin{array}{l}61 \\
80\end{array}$ & $\begin{array}{l}2.3 \\
2.0\end{array}$ & $\begin{array}{l}33 \\
20\end{array}$ & $\begin{array}{l}2.2 \\
2.0\end{array}$ & $\begin{array}{l}6 \\
1\end{array}$ & $\begin{array}{l}1.0 \\
0.8\end{array}$ & $\begin{array}{l}58 \\
64\end{array}$ & $\begin{array}{l}2.4 \\
2.3\end{array}$ & $\begin{array}{l}37 \\
36\end{array}$ & $\begin{array}{l}2.3 \\
2.3\end{array}$ & $\begin{array}{l}5 \\
1\end{array}$ & $\begin{array}{l}0.9 \\
0.8\end{array}$ \\
\hline \multicolumn{14}{|l|}{ Age (years) } \\
\hline $\begin{array}{l}18-34 \\
35-54 \\
55-73\end{array}$ & $\begin{array}{l}479 \\
445 \\
351\end{array}$ & $\begin{array}{l}73 \\
74 \\
65\end{array}$ & $\begin{array}{l}2.5 \\
2.6 \\
3.0\end{array}$ & $\begin{array}{l}25 \\
25 \\
29\end{array}$ & $\begin{array}{l}2.4 \\
2.6 \\
2.9\end{array}$ & $\begin{array}{l}2 \\
1 \\
6\end{array}$ & $\begin{array}{l}0.8 \\
0.4 \\
1.3\end{array}$ & $\begin{array}{l}67 \\
57 \\
57\end{array}$ & $\begin{array}{l}2.6 \\
3.0 \\
3.1\end{array}$ & $\begin{array}{l}31 \\
42 \\
38\end{array}$ & $\begin{array}{l}2.6 \\
2.9 \\
3.0\end{array}$ & $\begin{array}{l}2 \\
1 \\
4\end{array}$ & $\begin{array}{l}0.8 \\
0.3 \\
0.5\end{array}$ \\
\hline \multicolumn{14}{|c|}{ Smoking habits } \\
\hline $\begin{array}{l}\text { Nonsmoker } \\
\text { Ex-smoker } \\
\text { Smoker }\end{array}$ & $\begin{array}{l}697 \\
225 \\
353\end{array}$ & $\begin{array}{l}76 \\
73 \\
65\end{array}$ & $\begin{array}{l}2.0 \\
3.4 \\
2.8\end{array}$ & $\begin{array}{l}23 \\
24 \\
32\end{array}$ & $\begin{array}{l}2.0 \\
3.2 \\
2.8\end{array}$ & $\begin{array}{l}2 \\
3 \\
4\end{array}$ & $\begin{array}{l}0.6 \\
0.8 \\
1.4\end{array}$ & $\begin{array}{l}64 \\
67 \\
55\end{array}$ & $\begin{array}{l}2.2 \\
3.7 \\
3.0\end{array}$ & $\begin{array}{l}34 \\
31 \\
42\end{array}$ & $\begin{array}{l}2.2 \\
3.6 \\
3.0\end{array}$ & $\begin{array}{l}2 \\
3 \\
3\end{array}$ & $\begin{array}{l}0.5 \\
1.1 \\
0.9\end{array}$ \\
\hline \multicolumn{14}{|c|}{ Area of residence } \\
\hline $\begin{array}{l}\text { Urban } \\
\text { Rural }\end{array}$ & $\begin{array}{l}861 \\
414\end{array}$ & $\begin{array}{l}74 \\
64\end{array}$ & $\begin{array}{l}1.8 \\
2.2\end{array}$ & $\begin{array}{l}23 \\
34\end{array}$ & $\begin{array}{l}1.7 \\
2.3\end{array}$ & $\begin{array}{l}3 \\
2\end{array}$ & $\begin{array}{l}0.7 \\
0.5\end{array}$ & $\begin{array}{l}65 \\
52\end{array}$ & $\begin{array}{l}2.0 \\
2.9\end{array}$ & $\begin{array}{l}32 \\
46\end{array}$ & $\begin{array}{l}1.9 \\
2.9\end{array}$ & $\begin{array}{l}3 \\
2\end{array}$ & $\begin{array}{l}0.6 \\
0.7\end{array}$ \\
\hline Total & 1275 & 70 & 1.5 & 26 & 1.5 & 3 & 0.5 & 61 & 1.7 & 37 & 1.6 & 3 & 0.5 \\
\hline
\end{tabular}

a Ninety-nine subjects had never been employed. They were included among those with no occupational exposure.

Table 3. Occupational career of 122 men and 119 women born between 1921 and 1936 and holding an occupation with no airborne exposure $(A E-)$ or one with a moderate or high degree of airborne exposure $(A E+/ A E++)$ in 1957.

\begin{tabular}{|c|c|c|c|c|c|c|}
\hline & \multicolumn{2}{|c|}{1967 versus $1957^{a}$} & \multicolumn{2}{|c|}{1977 versus $1957^{a}$} & \multicolumn{2}{|c|}{1987 versus $1957^{a}$} \\
\hline & $\begin{array}{l}\text { Same } \\
\text { exposure } \\
\text { status } \\
(\%)\end{array}$ & $\begin{array}{c}\text { Different } \\
\text { exposure } \\
\text { status } \\
(\%)\end{array}$ & $\begin{array}{c}\text { Same } \\
\text { exposure } \\
\text { status } \\
(\%)\end{array}$ & $\begin{array}{c}\text { Different } \\
\text { exposure } \\
\text { status } \\
(\%)\end{array}$ & $\begin{array}{c}\text { Same } \\
\text { exposure } \\
\text { status } \\
(\%)\end{array}$ & $\begin{array}{c}\text { Different } \\
\text { exposure } \\
\text { status } \\
(\%)\end{array}$ \\
\hline \multicolumn{7}{|l|}{ Men } \\
\hline $\begin{array}{l}\text { AE - occupation }(N=68) \\
A E+I++ \text { occupation }(N=54)\end{array}$ & $\begin{array}{l}94 \\
89\end{array}$ & $\begin{array}{r}6 \\
10\end{array}$ & $\begin{array}{l}91 \\
80\end{array}$ & $\begin{array}{r}6 \\
16\end{array}$ & $\begin{array}{l}82 \\
54\end{array}$ & $\begin{array}{r}5 \\
25\end{array}$ \\
\hline \multicolumn{7}{|l|}{ Women } \\
\hline $\begin{array}{l}\mathrm{AE}-\text { occupation }(\mathrm{N}=72) \\
\mathrm{AE}+/++ \text { occupation }(\mathrm{N}=47)\end{array}$ & $\begin{array}{l}81 \\
46\end{array}$ & $\begin{array}{l}15 \\
54\end{array}$ & $\begin{array}{l}76 \\
33\end{array}$ & $\begin{array}{l}16 \\
56\end{array}$ & $\begin{array}{l}64 \\
19\end{array}$ & $\begin{array}{l}11 \\
56\end{array}$ \\
\hline
\end{tabular}


Table 4. Estimated lifetime prevalences, and their standard errors (SE), of occupational exposure to some agents and work processes for both the men and women and the estimated lifetime prevalences for the men by age and smoking habits.

\begin{tabular}{|c|c|c|c|c|c|c|c|c|c|c|}
\hline \multirow[b]{2}{*}{ Exposure } & \multicolumn{2}{|c|}{$\begin{array}{c}\text { Men } \\
(N=653)\end{array}$} & \multicolumn{2}{|c|}{$\begin{array}{c}\text { Women } \\
(\mathrm{N}=622)\end{array}$} & \multicolumn{3}{|c|}{ Age (years) group (men) } & \multicolumn{3}{|c|}{ Smoking habits (men) } \\
\hline & $\begin{array}{l}\text { Preva- } \\
\text { lence } \\
(\%)\end{array}$ & $\begin{array}{l}\text { SE } \\
(\%)\end{array}$ & $\begin{array}{c}\text { Preva- } \\
\text { lence } \\
(\%)\end{array}$ & $\begin{array}{l}\mathrm{SE} \\
(\%)\end{array}$ & $\begin{array}{c}18-34 \\
(N=274) \\
(\%)\end{array}$ & $\begin{array}{c}35-54 \\
(N=222) \\
(\%)\end{array}$ & $\begin{array}{c}55-73 \\
(N=157) \\
(\%)\end{array}$ & $\begin{array}{c}\text { Non- } \\
\text { smokers } \\
(\mathrm{N}=291) \\
(\%)\end{array}$ & $\begin{array}{c}\text { Ex- } \\
\text { smokers } \\
(\mathrm{N}=151) \\
(\%)\end{array}$ & $\begin{array}{c}\text { Smokers } \\
(\mathrm{N}=211) \\
(\%)\end{array}$ \\
\hline $\begin{array}{l}\text { Asbestos } \\
\text { Quartz } \\
\text { Aluminum } \\
\text { Wood dust } \\
\text { Metal gases } \\
\text { Welding } \\
\text { Soldering } \\
\text { Hairdressing }\end{array}$ & $\begin{array}{c}36 \\
17 \\
11 \\
12 \\
24 \\
25 \\
18 \\
0.6\end{array}$ & $\begin{array}{l}2.3 \\
1.7 \\
1.5 \\
1.5 \\
2.1 \\
2.1 \\
1.8 \\
0.3\end{array}$ & $\begin{array}{l}1.0 \\
1.0 \\
0.1 \\
1.0 \\
0.2 \\
0.2 \\
0.2 \\
2.1\end{array}$ & $\begin{array}{l}0.4 \\
0.3 \\
0.1 \\
0.3 \\
0.2 \\
0.1 \\
0.1 \\
0.7\end{array}$ & $\begin{array}{c}29 \\
15 \\
12 \\
12 \\
20 \\
22 \\
14 \\
1.0\end{array}$ & $\begin{array}{c}37 \\
18 \\
11 \\
14 \\
26 \\
27 \\
22 \\
0.2\end{array}$ & $\begin{array}{c}42 \\
18 \\
7 \\
9 \\
27 \\
25 \\
18 \\
0.3\end{array}$ & $\begin{array}{r}26 \\
12 \\
5 \\
9 \\
13 \\
17 \\
12 \\
0.2\end{array}$ & $\begin{array}{c}42 \\
23 \\
9 \\
13 \\
29 \\
26 \\
16 \\
0.3\end{array}$ & $\begin{array}{l}39 \\
15 \\
16 \\
12 \\
29 \\
29 \\
22 \\
1.0\end{array}$ \\
\hline
\end{tabular}

Table 5. Branches of industry and work processes in which those with exposure to asbestos, quartz, aluminum, or wood dust had been mainly exposed.

\begin{tabular}{lc}
\hline Agent & $\begin{array}{c}\text { Exposed workers } \\
(\%)\end{array}$ \\
\hline Asbestos & \\
Work in ship's engine room & 24 \\
Building and construction work & 18 \\
Mechanical work & 16 \\
Insulation work & 10 \\
Shipbuilding & 7 \\
Plumbing work & 6 \\
Unspecified & 19 \\
Quartz & \\
Construction work & 38 \\
Sandblasting & 15 \\
Tunneling & 9 \\
Road work & 8 \\
Mining & 2 \\
Foundry work & 1 \\
Unspecified & 27 \\
Aluminum & \\
Processing & 42 \\
Welding & 31 \\
Production & 27 \\
Wood dust & \\
Furniture industry & 27 \\
Sawmill work & 4 \\
Unspecified & 68 \\
\hline
\end{tabular}

The prevalences of those with past or present occupational exposure to specific agents or work processes increased significantly as the exposure level increased for an occupational title (table 6). The exception was hairdressing, and also soldering, when compared with the last job held. Those with $\mathrm{AE}+$ or $\mathrm{AE}++$ occupations had been exposed to the agents or work processes three to five times more often than those with AE - occupations. Occupational exposure to at least one of the specific agents or work processes was noted for $18 \%$ of the unexposed subjects versus $63 \%$ of the exposed, according to occupational title of the last job held. The corresponding figures according to the oc- cupational title of the job held the longest were 19 and $50 \%$, respectively.

\section{Discussion}

The present study presents a complete work history of a community sample. However, the self-reported information on the type of occupation and the length of employment may be subject to recall bias. The quality of such retrospective data has recently been examined through the linkage of interview data from a Swedish community survey, of 25586 subjects, to occupational information on the same individuals from a number of censuses (18). The occupational history by interview agreed very well with the census data in terms of occupational title. This finding is consistent with results of surveys on occupational groups $(19,20)$ in which employees' work histories were compared with the companies' registers. As would be expected, the quality of the data decreased with increasing time since the starting year of job and with the number of jobs held.

Asking people whether they had been occupationally exposed to isocyanates, aldehydes, and anhydrides was not successful, as a majority of the subjects did not know these agents. Future studies examining the type and level of occupational exposures in the general population should possibly focus more on work processes associated with potentially harmful agents rather than on the agents themselves. For instance, occupational exposure to isocyanates can be assessed by questions on the spray painting of cars.

The quality of the data may have been impaired by nonresponse bias. However, a survey of the nonparticipants in neither the first (10) nor in the second (table 1) phase of the study revealed any difference between the participants and the nonparticipants regarding gender, smoking habits, or occupational dust or gas exposure. The attendants to the second phase were, however, significantly older and more asbestosexposed than the nonattendants (table 1). But a re- 
Table 6. Prevalence of occupational exposure to specific agents and work processes among those with occupations with no $(\mathrm{AE}-)$, moderate $(\mathrm{AE}+)$, and high $(\mathrm{AE}++)$ airborne exposure according to the last job held and the job held longest. ${ }^{\mathrm{a}}(-=$ magnitude nil, $0=$ less than $0.5 \%$ ).

\begin{tabular}{|c|c|c|c|c|c|c|}
\hline \multirow[b]{2}{*}{ Exposure } & \multicolumn{3}{|c|}{ Last job held } & \multicolumn{3}{|c|}{ Job held longest } \\
\hline & $\begin{array}{c}A E- \\
(N=885) \\
(\%)\end{array}$ & $\begin{array}{c}A E+ \\
(N=341) \\
(\%)\end{array}$ & $\begin{array}{c}\mathrm{AE}++ \\
(\mathrm{N}=49) \\
(\%)\end{array}$ & $\begin{array}{c}A E- \\
(N=756) \\
(\%)\end{array}$ & $\begin{array}{c}A E+ \\
(N=474) \\
(\%)\end{array}$ & $\begin{array}{c}\mathrm{AE}++ \\
(\mathrm{N}=45) \\
(\%)\end{array}$ \\
\hline $\begin{array}{l}\text { Asbestos } \\
\text { Quartz } \\
\text { Aluminum } \\
\text { Wood dust } \\
\text { Metal gases } \\
\text { Welding } \\
\text { Soldering } \\
\text { Hairdressing }\end{array}$ & $\begin{array}{r}13 \\
6 \\
3 \\
4 \\
7 \\
7 \\
5 \\
1\end{array}$ & $\begin{array}{r}41 \\
17 \\
9 \\
17 \\
22 \\
26 \\
22 \\
3\end{array}$ & $\begin{array}{r}45 \\
65 \\
18 \\
22 \\
41 \\
45 \\
12 \\
0\end{array}$ & $\begin{array}{r}13 \\
7 \\
3 \\
4 \\
6 \\
7 \\
5 \\
1\end{array}$ & $\begin{array}{r}33 \\
14 \\
7 \\
13 \\
18 \\
21 \\
16 \\
3\end{array}$ & $\begin{array}{r}49 \\
58 \\
27 \\
18 \\
42 \\
47 \\
22 \\
0\end{array}$ \\
\hline $\begin{array}{l}\text { No exposure } \\
\text { One of the exposures } \\
\text { Two of the exposures } \\
\text { Three of the exposures } \\
\text { Four of the exposures } \\
\text { Five of the exposures } \\
\text { Six of the exposures }\end{array}$ & $\begin{array}{r}82 \\
8 \\
4 \\
3 \\
2 \\
1 \\
0\end{array}$ & $\begin{array}{r}42 \\
15 \\
14 \\
12 \\
11 \\
3 \\
2\end{array}$ & $\begin{array}{r}6 \\
27 \\
24 \\
14 \\
13 \\
16 \\
-\end{array}$ & $\begin{array}{r}81 \\
9 \\
4 \\
3 \\
2 \\
1 \\
0\end{array}$ & $\begin{array}{r}54 \\
12 \\
11 \\
10 \\
9 \\
3 \\
1\end{array}$ & $\begin{array}{r}7 \\
24 \\
22 \\
14 \\
15 \\
16 \\
2\end{array}$ \\
\hline
\end{tabular}

a Ninety-nine subjects had never been employed. They were included among those with no occupational exposure.

sponse rate of $100 \%$ would only have changed the mean age of the attendants from 42 to 41 years. Furthermore, if the rate of asbestos exposure of the nonattendants was only half of that of the attendants, the overall prevalence of asbestos exposure in the population would have changed from 18 to $16 \%$, as was estimated for the attendants only. An increased risk of death for highly exposed subjects may tend to underestimate the level of occupational lifetime exposure in the community.

The validity of the information regarding past or present occupational exposure to the agents and work processes is not known. However, subjects stating these exposures had higher gender-, age-, and smoking-adjusted odds ratios for obstructive lung disease than the unexposed did (4).

The division of occupations into three exposure groups will always, to some extent, be arbitrary. However, the high agreement between the allocations of the three experts in occupational medicine and hygiene indicates that this arbitrariness was limited. A recent Dutch community study (21) found that agricultural work was a stronger predictor of ever having been treated for asthma, bronchitis, or emphysema than various industrial jobs were. Hence, at least in The Netherlands, farmers should possibly be put into the $\mathrm{AE}++$ group, while our allocation was $\mathrm{AE}+$.

The higher prevalence of $\mathrm{AE}+$ and $\mathrm{AE}++$ jobs among the men than among the women and among the smokers than among the nonsmokers is compatible with findings of other community studies $(22,23)$. The gender difference in the prevalence of occupational exposure does not automatically imply that association between exposure and disease variables should be assessed separately for men and women (24). On the other hand separate analyses would be required if there were gender differences in the quality of exposure, biological sensitivity to exposure, or the distribution of potential confounders. Workers who are sensitive to tobacco smoke may avoid occupations with exposure to air pollution. In addition, the social environment in polluted workplaces may encourage workers to start smoking and discourage smokers to quit to a higher extent than the social environment of clean workplaces does (25).

The present study showed that workers tended to leave polluted occupations $(\mathrm{AE}+/++)$ more often than unpolluted occupations (AE-). According to data from Norwegian censuses in 1960, 1970, and 1980, the prevalences of $\mathrm{AE}+$ and $\mathrm{AE}++$ occupations in the population did not differ considerably during this period, being 23,27 , and $22 \%$ in the three censuses, respectively (26). Our finding does not necessarily suggest that a high level of airborne exposure makes workers find a cleaner job. It may be other health complaints [eg, musculoskeletal (27)] or it may be reasons unrelated to health [eg, salary (28), job satisfaction, and social esteem]. Interpretation of the occupational career of the 1921-1936 cohort should be cautious, as we studied the survivors. If the selection by death is higher for those with polluted jobs than for those with unpolluted jobs, the transition away from polluted jobs would be underestimated.

Our estimates of subjects ever having been exposed to specific agents and work processes potentially harmful to the lungs indicate that occupational exposure to these risk factors is widespread in the community. The estimates of lifetime prevalences of asbestos and quartz exposure were higher than those obtained from the same study population through a self-administered postal questionnaire (11). The postal questionnaire was primarily a questionnaire on respiratory disorders and smoking habits and contained six questions on asbestos and quartz exposure. In the second phase of the study 
the subjects recorded a complete work history and then answered detailed questions on asbestos and quartz exposure including the selection of printed alternatives for branch of industry or work process of main exposure. If the answers given in the latter questionnaire was a true picture of exposure, the postal questionnaire information on asbestos and quartz exposure had a sensitivity of 26 and $36 \%$, respectively, and a specificity of $98 \%$. Low sensitivity and high specificity for a question on asbestos exposure was also observed in a chest-radiograph survey of 21453 men 40 years of age or more in the county of Telemark, Norway (29). A prerequisite for any comparison of prevalences of airborne occupational exposures in different areas is identical methods of exposure recordings. When an exposure factor is not very common, low sensitivity is not too important. What is critical is a high specificity (30). Hence our findings indicate that self-administered questionnaires can be acceptable tools when the prevalence of occupational airborne exposure is being examined in the community. In the exposure-disease relationship any misclassification of exposure tends to underestimate the relationship, that is, if the misclassification is nondifferential (31).

In the county of Telemark (29) the main industries in which those with asbestos exposure had been exposed were electrochemical and chemical industries, building and construction industries, shipyards, and seafaring (machine rooms). The difference in industries and work processes reported as the main source of asbestos exposure in our study compared with that in the Telemark study may have been due to a difference in the industrial structure in the two study areas. Dissimilarities in the study design and the gender and age composition of the study populations may also have been of importance.

In an American community study including 2714 Anglo whites aged 18 years and over, $5.4 \%$ of the male working population reported that they had been exposed to silica at work (7). This is only one-third of the quartz exposure estimate in our study. The discrepancy could be due to differences in the industrial structure and geology of the study areas. Nicholson et al (32) have estimated that approximately $30 \%$ of male workers above 40 years of age in the United States have been exposed to asbestos. This estimate is in crude agreement with our finding.

Nineteen percent of those classified as unexposed according to the occupational title of the job held the longest had been exposed to one or more of the specific agents or work processes versus $93 \%$ of those highly exposed according to occupational title. The finding is compatible with that of a Norwegian case-referent study assessing the relationship between occupational airborne exposure and lung cancer among 256 men (33). This study found that $22 \%$ of the unexposed subjects, according to the job title of the job held the longest, had been exposed to at least three of 22 exposure factors. This finding may suggest that infor- mation on specific agents should be preferred to occupational titles when risk factors for disease are being assessed. On the other hand occupational title is easier to obtain and is less subject to recall bias than exposure to specific agents (34).

Furthermore, of those exposed to the specific agents or work processes, only a minority had been exposed to only one exposure factor. Thus, when assessing the relative importance of each exposure factor, one has to adjust for exposure to the other potentially adverse factors. This adjustment would require a large sample size in general population studies.

Exposure characterization according to last job held and job held the longest showed the approximate same ability to discriminate between those unexposed and those exposed to the agents and work processes (table 6). Wärneryd et al (18) found that the validity of the information on occupational title of the last job was higher than that of the job held the longest. This finding may suggest that one should ask for the last job rather than the longest job in studies in which exposure characterization is based only on one question on occupational title. However, whether to use the last job or the job held the longest as exposure characterization also depends on the aim of the study. If the objective is to examine the relationship of exposure to a chronic disease, the job held the longest should be preferred to the last job.

In summary, the present study indicates that occupational airborne exposure was widespread in a Nordic general population. A majority of those exposed reported exposure to two or more of the exposure factors.

\section{Acknowledgments}

This study was funded by the Royal Norwegian Council for Scientific and Industrial Research, the Norwegian Research Council for Science and the Humanities, the Norwegian Asthma and Allergy Association, and the Confederation of Norwegian Business and Industry. Professor T Norseth, Professor R Hanoa, and N Orlien, an occupational hygienist, performed the allocation of occupations into three exposure categories. Ms B Meidell is thanked for checking the completeness of the work history questionnaires.

\section{References}

1. Checkoway H, Pearce NE, Crawford-Brown DJ. Research methods in occupational epidemiology. New York, NY: Oxford University Press, 1989.

2. Kjuus $\mathrm{H}$, Skjærven R, Langård $\mathrm{S}$, Lien JT, Aamodt $\mathrm{T}$. A case-referent study of lung cancer, occupational exposures and smoking: I. comparison of title-based and exposure-based occupational information. Scand J Work Environ Health 1986;12:193-202.

3. Kvåle G, Bjelke E, Heuch I. Occupational exposure and lung cancer. Int J Cancer 1986;37:185-93.

4. Bakke P, Baste V, Hanoa R, Gulsvik A. Prevalence of 
obstructive lung disease in a general population: relationship to occupational title and exposure to some airborne agents. Thorax (in press).

5. Östlin P. Occupational history, self-reported chronic illness and mortality: a follow-up of 25586 Swedish men and women. J Epidemiol Community Health (in press).

6. Parkes RW. Occupational lung disorders. 2nd ed. London: Butterworths, 1982.

7. Lebowitz MD. Occupational exposure in relation to symptomatology and lung function in a community population. Environ Res 1977;14:59-67.

8. Stjernberg N, Rosenhall L, Eklund A, Nyström L. Chronic bronchitis in a community in Northern Sweden: relationship to environmental and occupational exposure to sulphur dioxide. Eur J Resp Dis 1986;69 Suppl 146: 153-9.

9. Central Bureau of Statistics of Norway. Population and housing census 1980: employment statistics. Oslo: Statistisk Sentralbyra, 1983.

10. Bakke $P$, Gulsvik A, Lilleng $P$, Overå $O$, Hanoa R, Eide GE. Postal survey on airborne occupational exposure and respiratory disorders in Norway: causes and consequences of nonresponse. J Epidemiol Community Health 1990;44:316-20.

11. Bakke P, Gulsvik A, Eide GE, Hanoa R. Smoking habits and lifetime occupational exposure to gases or dusts, including asbestos and quartz, in a Norwegian community. Scand J Work Environ Health 1990;16:195-202.

12. Bakke P, Eide GE, Hanoa R, Gulsvik A. Occupational dust or gas exposure and prevalences of respiratory symptoms and asthma in a general population. Eur Respir J 1991;4:273-8.

13. Arbeidsdirektoratet. Yrkesklassifisering: yrkesliste med NYK-nummer [Occupational classification]. Oslo: Arbeidsdirektoratet, 1984.

14. International Labour Office (ILO). International standard classification of occupations. Geneva: ILO, 1969.

15. Morgan WKC, Seaton A. Occupational lung diseases. Philadelphia, PA: WB Saunders Company, 1984.

16. Dixon JW, ed. BMDP statistical software manual. Berkeley, CA: University of California Press, 1985.

17. Armitage P, Berry G. Statistical methods in medical research. 2nd ed. Oxford: Blackwell Scientific Publication, 1987.

18. Wärneryd B, Thorslund M, Östlin P. The quality of retrospective questions on occupational history - a comparison between survey and census data. In: Östlin P. Occupational career and health [Doctoral dissertation]. Stockholm: Graphic Systems AB, 1989.

19. Bourbonnais R, Meyer F, Theriault G. Validity of self reported work history. Br J Ind Med 1988;45: 29-32.

20. Bond GG, Bodner KM, Sobel W, Shellenberger RJ, Flores GH. Validation of work histories obtained from interviews. Am J Epidemiol 1988;128: 343-51.

21. Heederik D, Pouwels H, Kromhout H, Kromhout D. Chronic non-specific lung disease and occupational ex- posures estimated by means of a job exposure matrix: the Zutphen study. Int J Epidemiol 1989;18:382-9.

22. Krzyzanowski M, Jedrychowski W, Wysocki M. Factors associated with the change of ventilatory function and the development of chronic obstructive pulmonary disease in a 13 years follow-up: the Cracow study. Am Rev Respir Dis 1986;134:1011-9.

23. Korn RJ, Dockery DW, Speizer FE, Ware JH, Ferris BG Jr. Occupational exposures and chronic respiratory symptoms: a population based study. Am Rev Respir Dis 1987;136:298 - 304.

24. Krzyzanowski M, Kauffmann F. The relationship of respiratory symptoms and ventilatory function to moderate occupational exposure in a general population: results from the French PAARC study of 16000 adults. Int J Epidemiol 1988;17:397-406.

25. United States Department of Health and Human Services. The health consequences of smoking - cancer and chronic lung disease in the workplace: a report of the Surgeon General. Rockville, MD: Office of Smoking and Health, Public Health Service, 1985.

26. Vassenden K. Folke-og boligtellingene 1960, 1970 og 1980. [Population and housing censuses 1960, 1970 and 1980]. Oslo: Statistisk Sentralbyrå, 1987.

27. Dimberg L, Olafsson A, Stefansson E, Aagaard H, Odén A, Andersson GBJ, et al. Sickness absenteeism in an engineering industry - an analysis with special reference to absence for neck and upper extremity symptoms. Scand J Soc Med 1989;17:77-84.

28. Hedberg GE, Lagendson SM. Factors influencing the turnover of Swedish professional drivers. Scand J Soc Med 1989;17:231-37.

29. Hilt B, Langảrd S, Lund-Larsen PG, Lien JT. Previous asbestos exposure and smoking habits in the County of Telemark, Norway - a cross-sectional population study. Scand J Work Environ Health 1986;12:561-6.

30. Kelsey JL, Thompson WD, Evans AS. Methods in observational epidemiology. New York, NY: Oxford University Press, 1986.

31. Flegal KM, Brownie C, Haas JD. The effects of exposure misclassification on estimates of relative risk. Am J Epidemiol;123:736-51.

32. Nicholson WJ, Perkel G, Selikoff IJ. Occupational exposure to asbestos: population at risk and projected mortality 1980-2030. Am J Ind Med 1982;3:259-311.

33. Kjuus $\mathbf{H}$. The role of combined occupational exposures in the development of some chronic diseases [Doctorial dissertation]. Oslo: The Norwegian Cancer Society, 1986.

34. Lemasters GK, Selevan SG. Use of exposure data in occupational reproductive studies. Scand J Work Environ Health $1984 ; 10: 1-6$.

Received for publication: 20 March 1991 